\title{
Az innovációs rendszerek mérési módszereinek feltérképezése és összefoglalása
}

\author{
Varga-Csajkás Anna \\ Pécsi Tudományegyetem
}

\begin{abstract}
A TANULMÁNY CÉLJA
A tanulmány célja, hogy összefoglalja, milyen módszerekkel mérhető, illetve modellezhető az innovációs rendszerek teljesítménye. Az ismertetett módszerek három típusba sorolhatók funkciójuk alapján. Az első csoportba azok a módszerek tartoznak, amelyek alkalmasak arra, hogy értékeljék és összehasonlítsák különböző országok vagy régiók innovációs rendszereinek teljesítményét. A második csoportot olyan statisztikai alapú modellek alkotják, amelyek segítségével az innovációs rendszerek teljesítményére ható tényezők szerepe magyarázható. A harmadik csoportba olyan szimulációs módszerek sorolhatók, amelyek alkalmasak a változók közötti komplex, dinamikus kapcsolatok modellezésére.
\end{abstract}

\section{ALKALMAZOTT MÓDSZERTAN}

Ez a tanulmány egy leíró jellegü munka, amelyben szisztematikusan végig vesszük és csoportosítjuk az innovációs rendszerek mérésére és modellezésére használt legföbb eszközöket. A módszerek lényegének bemutatása után példákkal illusztráljuk, hogy milyen elemzések végezhetők a segítségükkel.

\section{LEGFONTOSABB EREDMÉNYEK}

A vizsgált módszerek funkciójukat, adatigényüket és komplexitásukat tekintve eltérnek egymástól, ezért az elemzés céljától és a rendelkezésre álló adatoktól függ, hogy melyik eszköz a legalkalmasabb. A kompozit indikátorok jó kiindulási pontot jelentenek, mivel sokféle tényezőt képesek egyetlen indikátorba tömöríteni. Az innovációs rendszerek abszolút teljesítményének és hatékonyságának elkülönítése fontos, mivel gyakran nem a legmagasabb innovatív outputtal rendelkező országok vagy régiók használják fel leghatékonyabban a rendelkezésre álló inputokat. A különböző statisztikai, ökonometriai módszerek alkalmasak arra, hogy beazonosítsák, hogy a vizsgált tényezők milyen mértékben hatnak a rendszer teljesítményére. Az innovációs rendszerek komplexitását legjobban a szimulációs módszerek ragadják meg.

\section{GYAKORLATI JAVASLATOK}

Minden vizsgált módszer alkalmas lehet arra, hogy a szakpolitikai döntéshozást segítse. A kompozit indikátorok különböző dimenzióinak elemzésével például beazonosíthatók a rendszer gyenge pontjai, ahol szükség lehet beavatkozásokra. A szimulációs modellekkel ex-ante elemzéseket lehet végezni, amelyek során szakpolitikai beavatkozások hatása értékelhető.

Kulcsszavak: innovációs rendszerek, módszertan, kompozit indikátorok, tudástermelési függvény, szimulációs modellek

Köszönetnyilvánitás: Jelen publikáció az Európai Unió, Magyarország és az Európai Szociális Alap társfinanszírozása által biztosított forrásból az EFOP-3.6.2-16-2017-00017 azonosítójú „Fenntartható, intelligens és befogadó regionális és városi modellek" című projekt keretében jött létre.

DOI: 10.15170/MM.2020.54.KSZ.I.02 


\section{BEVEZETÉS INTRODUCTION}

Az innovációs rendszerek (IR) koncepciójának lényege, hogy az innováció nem elszigetelten müködő egyének önálló tevékenységének eredménye, hanem adott intézményi környezetben, a különböző szereplők interakciói során létrejövó jelenség. Az IR megközelítés egy koncepcionális keretrendszer (Edquist 2005), ami mind a tudományos kutatásoknak mind a szakpolitika támogatásának fontos eszköze. Elsőként a nemzeti innovációs rendszerek elmélete jelent meg a szakirodalomban az egyes országok innovatív teljesítményét meghatározó rendszerelemek vizsgálata kapcsán (Freeman 1987, Nelson 1993, Lundvall 1992). Később az elemzés fókusza szerint három másik irányzat született: a regionális innovációs rendszerek (Cooke et al. 1997, Braczyk et al. 1998), a szektorális innovációs rendszerek (Malerba 2002), valamint a technológiai innovációs rendszerek (Carlsson \& Stankiewicz 1991, Bergek et al. 2008) koncepciója.

Ebben a tanulmányban különböző módszereket mutatunk be, amelyekben az a közös, hogy számszerüsíteni képesek az innovációs rendszerek teljesítményét. A módszerek nagy része a regionális és nemzeti innovációs rendszerek mérését szolgálja. Ennek egyik oka, hogy összehasonlítható adatok föleg területi egységekre érhetők el, szektorokra vagy technológiákra kevésbé. Másrészt a szakpolitikai döntéshozás fókuszában is általában egy-egy ország vagy régió áll. A tanulmány során vizsgált módszerek három csoportra oszthatók funkciójuk alapján. Az első csoportba azok tartoznak, amelyekkel az innovációs rendszerek teljesítménye, illetve hatékonysága mérhető és összehasonlítható. A második csoportot ezzel szemben olyan statisztikai alapú modellek alkotják, amelyek segítségével lehetséges az innovációs rendszer teljesítményére ható tényezők szerepének meghatározása. A harmadik kategóriába az innovációs rendszerek komplexitását is megragadó szimulációs módszereket soroltuk. Azon felül, hogy az innovációs rendszer teljesítményét meghatározó tényezőket beazonosítsák, ezek alkalmasak arra, hogy különböző szakpolitikai forgatókönyveket elemezhessünk velük.

\section{AZ INNOVÁCIÓS RENDSZEREK TELJESÍTMÉNYÉT MÉRŐ MÓD- SZEREK \\ METHODS FOR MEASURING THE PERFORMANCE OF INNO- VATION SYSTEMS}

Az első csoportot azok a módszerek alkotják, amelyek alkalmasak arra, hogy értékeljék és összehasonlítsák különböző országok vagy régiók innovációs rendszereinek valamilyen értelembe vett teljesítményét. Ez lehet abszolút eredmény vagy hatékonyság is, a lényeg, hogy számszerủ eredményt ad minden egyes vizsgált rendszer teljesítményére. A kompozit indikátorokon kívül ide tartoznak a hatékonyság mérésére szolgáló modellek is.

\section{Kompozit indikátorok Composit indicators}

A kompozit indikátorok olyan valós értékü méröszámok, amelyeket egyedi indikátorok halmazából számítanak valamilyen összesítő módszer segítségével (Grupp \& Schubert 2010). Ezek eredményét egy értékelő táblában jelenítik meg, amelyben sorba állítják az egyes megfigyelési egységeket az általuk elért indexértékek alapján. A sorrend alakulásának elemzése rendszerint kiegészül a különböző részindexek értékelésével, vizuális megjelenítésével, valamint az országok vagy régiók profiljának vizsgálatával. A kompozit indikátorok összeállításánál ki kell választani a releváns egyedi indikátorokat, meg kell határozni, hogy a változókat hogyan normalizálják, végül el kell dönteni, hogy milyen módon egyesítsék öket (Cherchye et al. 2004). A módszer korlátai elsősorban abból fakadnak, hogy nincs egyértelmủ elmélet, ami az indikátorok kiválasztását és súlyozását megalapozná (Grupp \& Schubert 2010).

Kiinduló pontnak tekinthető az Európai Innovációs Eredménytábla (European Innovation Scoreboard, EIS) és annak régiókra kiterjesztett változata. Az EIS alapvetően az Európai Unió országainak innovációs rendszereit méri össze egymással. Segítségével komparatív elemzés végezhető az országok innovatív teljesítményei között, és beazonosíthatók a nemzeti innovációs rendszerek relatív gyengeségei és erősségei, ami segít meghatározni azokat a területeket, amelyekre érdemes koncentrálni (Európai Bizottság 2019). Az Összevont Innovációs Index (Summary Innovation Index, SII) egyetlen számmal fejezi ki a 
rendszer teljesítményét, és ez alapján készül egy rangsor a vizsgált országokról. Az SII-t jelenleg 27 indikátor egyszerü számtani átlagaként számítják. Az adatok forrása többnyire az Eurostat, de néhány esetben specifikus adatbázisokat használnak. A 27 egyedi indikátorból 10 dimenziót képeznek, amelyeket külön-külön is értékelnek.

Területi szempontból a legátfogóbb kompozit indikátor a világ gazdaságait innovációs képességeik és eredményeik alapján rangsoroló Globális Innovációs Index (Global Innovation Index, GII) amelyet a Cornell University, az INSEAD üzleti föiskola és a Szellemi Tulajdon Világszervezete (WIPO) közösen publikál (Dutta et al. 2019). A GII nem csak az innovációs rendszer abszolút teljesítményének, hanem a rendszer hatékonyságának mérésére is alkalmas. Ennek érdekében két alindexet különítenek el: az innovációs input és az innovációs output alindexet, amelyek különböző pillérekre és alpillérekre épülnek, és 80 egyedi indikátort összesítenek. Az összesített GII index az input és output alindex számtani átlagaként adódik, míg az innovációs hatékonysági arányt az output és input alindex arányából számítják. Olyan nemzetközi szervezetek, mint a Világbank, az IMF, a WTO, az ENSZ, a WIPO, az UNESCO és a Világgazdasági Fórum adatbázisai szolgálnak alapul az index elkészítéséhez. Összehasonlítva az EIS eredményeit a GII-ben szereplö Európai uniós országok eredményeivel, mindkét esetben Svédország vezeti a rangsort, és az első 10 helyen egy kivétellel ugyanazok az országok helyezkednek el, csak eltérő sorrendben.

\section{Sztochasztikus határfelület-elemzés Stochastic frontier analysis}

A sztochasztikus határfelület-elemzés (Stochastic Frontier Analysis, SFA) a gazdasági egységek hatékonyságmérésének irodalmából került át az innovációs elemzésekbe. A módszer lényege, hogy egy termelési függvény becslésével határozzák meg, hogy mennyi lenne az adott inputokkal elérhető maximális output (Aigner et al. 1977, Meeusen \& Van den Broeck 1977). Az innovációs rendszerek hatékonysága esetén egy tudástermelési függvény (Griliches 1979) segítségével empirikus adatok alapján létrehoznak egy határoló görbét, ami a maximális tudáskibocsátást reprezentálja. A hatékonyság a megfigyelt tudáskibocsátás és a lehetséges maximális kibocsátás hányadosaként értelmezhető.
Fritsch és Slavtchev (2011) a regionális innovációs rendszerek hatékonyságát hasonlította össze egy a tudástermelési függvényre épülö SFA becslés segítségével. Az innovációs outputot a szabadalmi bejelentések számával mérték, és a $\mathrm{K}+\mathrm{F}$ foglalkoztatottak számát tekintették az egyetlen közvetlen inputnak. Hasonló módszert alkalmazott Fu és Yang (2009) is 21 OECD ország szabadalmazási hatékonyságának összehasonlítására. Az általuk számított hatékonysági pontszámokat összehasonlították többek közt a GII és az EIS eredményeivel, és azt tapasztalták, hogy van bizonyos fokú korreláció közöttük. ${ }^{1}$

\section{Burkolófelület-elemzés Data envelopment analysis}

A burkolófelület-elemzés (Data Envelopment Analysis, DEA) az SFA-val ellentétben egy nem parametrikus módszer a gazdasági-társadalmi egységek hatékonyságának mérésére, amely az operációkutatás eszköztárát alkalmazza. A vizsgált társadalmi-gazdasági egységeket döntéshozó egységeknek (Decision Making Units, DMU) nevezik, amelyekre jellemző, hogy több input felhasználásával egy vagy több outputot hoznak létre. A DEA módszer lényege, hogy az adatokból kiindulva lineáris programozási módszerek segítségével előállítják a hatékony pontok felületét, és a vizsgált pontok hatékonyságát ehhez a felülethez viszonyítva határozzák meg (Fülöp - Temesi 2001). A DEA alapját képezi a relatív hatékonyság fogalma, miszerint akkor és csak akkor ér el teljes hatékonyságot egy DMU, ha egyetlen inputja vagy outputja sem fejleszthető anélkül, hogy egy másik inputja vagy outputja romlana (Cooper et al. 2011).

Nasierowski és Arcelus (2003) használt először DEA módszert a nemzeti innovációs rendszerek elemzésére. A hatékonyságot a 'best practice' által kijelölt határolóhoz képest lehet értelmezni, amit az elemzésbe bevont 45 országból kialakított hipotetikus DMU alkot. Az alapmodellek egyik kiterjesztése a hálózati DEA modellek csoportja, amelyekben a részfolyamatok hálózatát is figyelembe veszik, és ezek összefüggéseit is formalizálják (Lu et al. 2014). Ehhez hasonlóan a különbözö időszakok között is kapcsolatot lehet teremteni a dinamikus DEA modellekkel, valamint dinamikus hálózati DEA modellek is léteznek, amelyek az egymást követő időszakok összefüggését és a részfolyamatok kapcsolatát egyaránt magukba foglalják (Guan \& Chen 2012, Kou et al. 2016). Matei és

Saját számításunk szerint 0,48 a korreláció a GII, és 0,72 az EIS esetén. 
Aldea (2012) megvizsgálta, hogy az EIS kompozit indexe szerint a vezető innovátor kategóriába tartozó országok egyben technikailag is hatékonyak-e. Eredményeik szerint viszont nem a vezető, hanem a jelentős és a mérsékelt innovátorok közül kerülnek ki a leghatékonyabbak. Regionális szinten vizsgálódva Zabala-Iturriagagoitia és szerzőtársai (2007) is hasonló eredményre jutottak.

\section{AZ INNOVÁCIÓS RENDSZEREK TELJESÍTMÉNYÉT MAGYARÁZÓ MODELLEK \\ MODELS EXPLAINING THE PERFORMANCE OF INNOVATION SYSTEM}

Míg az előző fejezetben olyan módszereket mutattunk be, amelyek az innovációs rendszer teljesítményét mérték, ebben a fejezetben olyan statisztikai alapú modelleket ismertetünk, amelyek arra adnak választ, hogy a vizsgált tényezők milyen mértékben hatnak a rendszer teljesítményére. Itt tehát már nem a különböző országok és régiók egymáshoz viszonyított teljesítményén van a hangsúly, hanem az azt befolyásoló tényezőkön. Ezek közül a legismertebb módszer a regresszióelemzés, ezért a többi eszközt is ehhez viszonyitva mutatjuk be.

\section{Regresszióelemzés \\ Regression analysis}

A regresszióelemzés célja korrelációs kapcsolatok feltárása az innovációs rendszer teljesítménye és az azt meghatározó tényezők között. Az innovációs rendszerek mérésére szolgáló modellek egyik fö irányát a tudástermelési függvények (Knowledge Production Function, KPF) jelentik, amelyek széles szakirodalmi bázissal rendelkeznek. A kutatás-fejlesztés inputjainak és outputjának számbavétele és egy termelési függvényben való ábrázolása Griliches (1979) munkájában jelent meg először. Azóta számos tanulmányban foglalkoztak kifejezetten a régiók tudástermelésének ökonometriai elemzésével (lásd: Varga - Horváth 2014). Jaffe (1989) fektette le a regionális tudástermelés inputjai és outputja közötti alapvető összefüggést egy Cobb-Douglas termelési függvény formájában, majd Feldman (1994), Anselin és szerzőtársai (1997), valamint Varga (1998)-munkája során fejlödött tovább a módszer.

A regressziót alkalmazó innovációs rendszer kutatások másik kapcsolódó ága a nemzeti innovációs rendszerek kapacitását meghatározó tényezők feltárására irányul. Furman és szerzőtársai (2002) három elméleti megközelítést ötvöz a nemzeti innovációs kapacitás meghatározásánál: az endogén növekedési elméletet, a Porter-féle versenyelőnyöket, és az innovációs rendszerek elméletét. Definíciójuk szerint az innovációs kapacitás az ország potenciálját fejezi ki arra vonatkozóan, hogy menynyiben képes a piaci szempontból releváns innovációk sorát elő́llítani. A KPF-hez hasonlóan egy termelési függvényből indulnak ki, de a mögöttes elméletnek megfelelően más magyarázó változókat vonnak be az elemzésbe.

\section{Strukturális egyenlet modellek Structural equation modeling}

A strukturális egyenletekkel való modellezés (Structural Equation Modeling, SEM) egy olyan többváltozós statisztikai módszer, amely a regreszsziós modellekhez hasonló összefüggések feltárására alkalmas, de ebben az esetben nem csak mérhető, hanem látens változók közötti kapcsolatok is beazonosíthatók, valamint a változók direkt, indirekt és teljes hatása külön értelmezhető (Kalapouti et al. 2017). A SEM modellek két része különíthető el: a mérési modell és a strukturális modell (Bowen \& Guo 2011). A mérési modell lényege, hogy a kompozit indikátorokhoz hasonlóan egy közvetlenül nem megfigyelhető (látens) jelenséget több változóval együttesen közelítenek, a strukturális rész pedig a változók közötti regressziós összefüggéseket takarja. Sleuwaegen és Boiardi (2014) a regionális innovációs infrastruktúra, intézmények, intelligencia és inspirációk szabadalmi intenzitásra gyakorolt hatását vizsgálta egyrészt közvetlenül, másrészt a $\mathrm{K}+\mathrm{F}$ kiadásokon keresztül. Mivel ezek a strukturális modellben szereplő magyarázó változók nem megfigyelhetők, ezért különböző mérhető indikátorokat használtnak, amelyekről azt feltételezték, hogy mindegyikre hatással van az adott látens változó. $\mathrm{Az}$ intelligenciát, mint látens változót például a felsőfokú végzettségüek és a tudományos és technológiai végzettségúek arányával közelítették.

\section{Kvalitatív összehasonlitó elemzések Qualitative comparative analysis}

A társadalomtudományokban a statisztikai-ökonometriai módszerek egy része nem használható, mivel a megfigyelési egységek száma alacsony. Ilyenkor inkább kvalitatív módszereket alkalmaznak, de gyakran felmerül az igény az eredmények általánosítására, számszerüsítésére. A kvalitatív 
összehasonlító elemzésekben (Qualitative Comparative Analysis, QCA) ötvözik az egyedi esetekre fókuszáló (kvalitatív) elemzéseket és a változóorientált (kvantitatív) módszereket (Ragin 1987). A QCA a gyakorlatban a Boole-algebra számítógépes programokkal való alkalmazását jelenti. $\mathrm{Az}$ ökonometriai elemzésekkel szemben itt nem eredményváltozóról és független változókról beszszélhetünk, hanem kimenetekről és feltételekről, és arra keresik a választ, hogy a feltételek milyen kombinációi mellett valósul meg az adott kimenet. Az eredeti QCA módszer alapján a konfigurációk csak 0 és 1 értékekböl épülnek fel, ehhez képest a fuzzy-set QCA (fsQCA) módszer (Ragin 2000), megengedi, hogy a változók 0 és 1 között bármilyen valós értéket felvegyenek (Rihoux 2006).

A QCA elemzések használatát nem csak az alacsony elemszám indokolhatja, hanem az is, hogy lehetőség nyílik a különböző indikátorok kölcsönös összefüggéseinek vizsgálatára. További előnye, hogy a regressziós elemzéssel ellentétben be lehet azonosítani olyan eseteket, amikor különböző megoldások vezetnek ugyanarra az eredményre. Ezt használta ki Porksch és szerzőtársai (2017) az innovációs kapacitást meghatározó tényezők beazonosítása során, amelyhez Furman és szerzőtársai (2002) regressziós elemzését vették alapul. Különbözö utakat azonosítottak be, amelyek eltérő innovációs stratégiáknak felelnek meg, de mind a magasabb innovatív kapacitás elérését eredményezik. Khedhaouria és Thurik (2017) hasonló fsQCA elemzést végzett az innovációs képesség vonatkozásában a GII-ben szereplő adatok felhasználásával. Ferreira és Dionísio (2016) az EIS adatai alapján fsQCA módszerrel tárta fel, hogy milyen feltételek megléte járul hozzá az innovációhoz.

\section{SZIMULÁCIÓS MÓDSZEREK SIMULATION METHODS}

Az eddig bemutatott módszerekkel csak korlátozottan lehet figyelembe venni az innovációs rendszerek komplex jellegét. Az ilyen összetett folyamatok modellezésére különböző szimulációs módszerek lehetnek alkalmasak. Ezek közül a rendszerdinamikai modellezés (System Dynamics, SD) és az ágens-alapú modellezés (Agent-Based Modeling, $\mathrm{ABM}$ ) terjedt el az innovációs irodalomban. Mindkét esetben igaz, hogy a modellek jelentős része a koncepcióalkotást, illetve a meglévő koncepcionális modellek formalizálását szolgálja. Ezzel szemben születtek olyan modellek is, amelyeket empirikus adatokkal validáltak és kalibráltak, tehát úgy alkottak meg, hogy egy adott innovációs rendszert minél élethűbben megragadjanak. A szimulációs módszerek gyakorlati haszna a szakpolitika szempontjából, hogy ex-ante hatáselemzéseket lehet velük végezni, amelyek során különböző alternatív beavatkozások hatása értékelhető.

\section{Rendszerdinamikai modellezés System dynamics}

A rendszerdinamika komplex, dinamikus rendszerek vizsgálatára alkalmas módszer, ezért az innovációs rendszerek mechanizmusai jól megragadhatók vele (Uriona \& Grobbelaar 2019). Előnye, hogy képes a nem-egyensúlyi folyamatok modellezésére, és a rendszer elemei közötti visszacsatolási hurkok megragadására. Top-down megközelítés jellemzi, tehát a teljes rendszer vizsgálatából indul ki, nem az egyes szereplök viselkedéséből. Minden SD modell differenciál- vagy differenciaegyenletek összessége, amelyek eljuttatják a vizsgált rendszert a kiindulóhelyzetből egy jövőbeli szimulált állapotba (Gilbert \& Troitzsch 2005).

A modellek reprezentálására két alapvető eszközt használnak a rendszerdinamikában: az okozati lánc diagramot (causal loop diagram), ami egy kvalitatív eszköz, és a visszacsatolási hurkok szemléltetésére alkalmas, valamint a folyamat diagramot (stock and flow diagram), amelyben megjelenik az állomány és folyamat jellegű változók közötti számszerü kapcsolat.

Walrave és Raven (2016) munkájának célja, hogy a technológiai innovációs rendszerek kialakulásának koncepcionális modelljét SD módszerrel formalizálja. A lefuttatott szimulációk során a modell képes volt olyan eredményeket produkálni, ami a szakirodalom alapján várható volt. Az empirikus adatok felhasználása és azok alapján a modell validálása viszont esetükben nem volt cél. Ezzel szemben Rodriguez és Navarro-Chávez (2015) a feltörekvő országok regionális innovációs rendszerét leíró rendszerdinamikai modellt épített, és egy mexikói tartomány adatai alapján validálta és kalibrálta azt. Tanulmányuk nem tartalmazza alternatív szakpolitikai intézkedések hatáselemzését, de megjegyzik, hogy erre is lenne lehetőség a modellkeretben. Samara és tsai (2012) viszont kifejezetten az innovációpolitikai beavatkozások nemzeti innovációs rendszerre gyakorolt hatását vizsgálta rendszerdinamikai modelljével. 


\section{Ágens-alapú modellezés Agent-based modeling}

Az innovációs folyamat számos társadalmi jelenséghez hasonlóan nem vezethető le a változók aggregált értékeiből, éppen ezért érdemes ágens alapú szimulációt alkalmazni (Pyka et al. 2009), amelynek segítségével a mikroszintü interakciókból felépülö, úgynevezett emergens folyamatként ábrázolhatjuk az innovációt. Ez a megközelítés lehetővé teszi, hogy heterogén szereplőkként kezeljük az innovációs folyamatban résztvevő ágenseket, akik a modellben megadott tulajdonságaik és viselkedési szabályaik alapján interakcióba lépnek egymással és a környezetükkel. Az innováció dinamikájának ágens alapú modellezésében mérföldkőnek számít a Simulating Knowledge Dynamics in Innovation Networks (SKIN) elnevezésủ modell (Ahrweiler et al. 2004). Ebben az esetben az ágensek vállalatokat testesítenek meg, amelyek innovációs tevékenységet folytatnak egyénileg vagy egymással kooperálva. Viselkedésüket egyrészt a tudásbázisuk, másrészt egyéb paraméterek határozzák meg. Korber és szerzőtársai (2009) a SKIN modellt alkalmazták a bécsi biotechnológiai szektorra mint innovációs rendszerre. A bécsi adatokat felhasználva kalibrálták a modellt, és szimulációk során vizsgálták a $\mathrm{K}+\mathrm{F}$ támogatások különböző típusainak hatását (Korber \& Paier 2013, 2014, Paier et al. 2017). Schrempf és Ahrweiler (2014) általános célú technológiák megjelenését vizsgálták az ír nanotechnológiai szektor példáján keresztül, míg Kwon és Motohashi (2017) az Amerikai Egyesült Államok és a Japán nemzeti innovációs rendszerét modellezte.

A SKIN modellen kívül több olyan ágens alapú modell is megjelent az elmúlt 10-15 évben, amelyek alkalmasak valamely innovációs rendszer viselkedésének szimulálása. Ilyen Ponsiglione és szerzőtársainak (2018) munkája, amelyben a komplex adaptív rendszer megközelítést építik be a regionális innovációs rendszerek elemzési keretébe. Kutatásuk különösen releváns a lemaradó régiók számára, ahol a szakpolitikai beavatkozások ellenére sem alakult ki megfelelö alap az innovációhoz. Antonelli és Ferraris (2011) az innováció mint emergens rendszertulajdonság leírására hoz létre egy elméleti modellt, amelyben egyesíti az innováció gazdaságtanát és a komplexitás gazdaságtanát.

\section{ÖSSZEGZÉS SUMMARY}

Az innovációs rendszerek mérési és modellezési lehetőségeit feldolgozó elemzésben összesen nyolc különböző módszert mutattunk be, amelyeket három csoportra osztottunk funkciójuk alapján. Az első csoportba az innovációs rendszerek teljesítményét mérő módszerek kerültek, a másodikba ezt a teljesítményt magyarázó modellek, míg a harmadikba a rendszer elemei közötti dinamikus kapcsolatokat számítógépes programokkal szimuláló modellek. Az egyes csoportokon belül bemutatott eszközök jellemzően egymás helyettesítőjeként funkcionálhatnak, mivel hasonló célt szolgálnak. Az eredmények összehasonlításából mégis fontos következtetéseket lehet levonni. Látható például, hogy az innovációs rendszerek abszolút teljesítményének és hatékonyságának elkülönítése fontos, mivel gyakran nem a legmagasabb innovatív outputtal rendelkező országok vagy régiók használják fel leghatékonyabban a rendelkezésre álló inputokat. Erre mutatnak rá azok a DEA elemzések is, amelyekben a kompozit innovációs indikátorokban is alkalmazott adatokat használják hatékonyságmérésre. A különböző csoportokban szereplő módszerek viszont inkább egymást kiegészítve múködnek. A regressziós elemzések például azon túl, hogy önálló tanulmányok tárgyát képezik, más módszerekkel végzett vizsgálatokban is gyakran megjelennek. A hatékonyság mérésére szolgáló SFA elemzéseknél például a sztochasztikus határ megállapításához többnyire tudástermelési függvényt becsülnek, és az ágens alapú modellek egyes paramétereit is gyakran ökonometriai becsléssel határozzák meg. Mivel a vizsgált módszerek funkciójukat, adatigényüket és komplexitásukat tekintve jelentősen eltérnek egymástól, ezért az elemzés céljától és a rendelkezésre álló adatoktól függ, hogy melyik eszköz a legalkalmasabb. Ez az összefoglaló további kutatások megalapozásához lehet hasznos, mivel támpontot nyújt az innovációs rendszerek mérési módszerének kiválasztásához. 


\section{HIVATKOZÁSOK REFERENCES}

Ahrweiler, P., Pyka, A. \& Gilbert, N. (2004), Simulating knowledge dynamics in innovation networks (SKIN). In: Industry and labor dynamics: The agent-based computational economics approach. 284-296.

Aigner, D., Lovell, C.K. \& Schmidt, P. (1977), "Formulation and estimation of stochastic frontier production function models." Journal of Econometrics, 6(1), 21-37. DOI: 10.1016/03044076(77)90052-5

Anselin, L., Varga, A. \& Acs, Z. (1997), "Local geographic spillovers between university research and high technology innovations." Journal of Urban Economics, 42(3), 422-448. DOI: 10.1006/juec.1997.2032

Antonelli, C., \& Ferraris, G. (2011), 'Innovation as an emerging system property: an agent based simulation model." Journal of Artificial Societies and Social Simulation, 14(2), 1. DOI: 10.18564/jasss.1741

Braczyk, H.J., Cooke, P.N. \& Heidenreich, M. (Eds.). (1998), Regional innovation systems. the role of governances in a globalized world. Psychology Press.

Bergek, A., Jacobsson, S., Carlsson, B., Lindmark, S. \& Rickne, A. (2008), "Analyzing the functional dynamics of technological innovation systems: A scheme of analysis." Research Policy, 37(3), 407-429. DOI: 10.1016/j. respol.2007.12.003

Bowen, N.K. \& Guo, S. (2011), Structural equation modeling. Oxford University Press.

Carlsson, B. \& Stankiewicz, R. (1991), "On the nature, function and composition of technological systems." Journal of Evolutionary Economics, 1(2), 93-118. DOI: 10.1007/bf01224915

Cherchye, L., Moesen, W. \& Puyenbroeck, T. (2004), "Legitimately diverse, yet comparable: on synthesizing social inclusion performance in the EU." JCMS: Journal of Common Market Studies, 42(5), 919-955. DOI: 10.1111/j.00219886.2004.00535.x

Cooke, P., Uranga, M. G. \& Etxebarria, G. (1997), "Regional innovation systems: Institutional and organisational dimensions." Research Policy, 26(4-5), 475-491. DOI: 10.1016/s00487333(97)00025-5

Cooper, W. W., Seiford, L. M. \& Zhu, J. (Eds.). (2011), Handbook on data envelopment analysis (Vol. 164). Springer Science \& Business Media.
Dutta, S., Lanvin B. \& Wunsch-Vincent, S. (Eds.). (2019), "The Global Innovation Index 2019: Creating Healthy Lives - The Future of Medical Innovation." https:/www.globalinnovationindex.org/userfiles/file/reportpdf/giifull-report-2019.pdf (letöltve: 2020.04.06.)

Edquist, C. (2005), Systems of innovation: technologies, institutions and organizations. Routledge.

Európai Bizottság (2019), European Innovation Scoreboard 2019. Methodology Report. Letöltve: 2020.01.16 https://ec.europa.eu/docsroom/documents/36282/attachments/1/translations/en/renditions/native

Feldman, M.P. (1994), The Geography of Innovation (Economics of Science, Technology and Innovation). The Netherland: Kluwer Academic Publisners.

Ferreira, P.J.S., \& Dionísio, A.T.M. (2016), ’What are the conditions for good innovation results? A fuzzy-set approach for European Union." Journal of Business Research, 69(11), 53965400. DOI: 10.1016/j.jbusres.2016.04.144

Freeman, C. (1987), Technology policy and economic performance, Pinter: London

Fritsch, M., \& Slavtchev, V. (2011), ’Determinants of the efficiency of regional innovation system." Regional Studies, 45(7), 905-918. DOI: 10.1080/00343400802251494

Fu, X., \& Yang, Q. G. (2009), ”Exploring the cross-country gap in patenting: A stochastic frontier approach." Research Policy, 38(7), 1203-1213. DOI: 10.1016/s00487333(01)00152-4

Furman, J. L., Porter, M. E., \& Stern, S. (2002), "The determinants of national innovative capacity." Research Policy, 31(6), 899-933.

Fülöp J. \& Temesi J. (2001), "A Data Envelopment Analysis (DEA) alkalmazása ipari parkok hatékonyságának vizsgálatára." Szigma, 32(34) $85-109$

Gilbert, N. \& Troitzsch, K. (2005), Simulation for the social scientist. McGraw-Hill Education (UK).

Griliches, Z. (1979), 'Issues in assessing the contribution of research and development to productivity growth." The Bell Journal of Economics, 92-116. DOI: $10.2307 / 3003321$

Grupp, H. \& Schubert, T. (2010), "Review and new evidence on composite innovation indicators for evaluating national performance." Research Policy, 39(1), 67-78. DOI: 10.1016/j. respol.2011.07.001

Guan, J. \& Chen, K. (2012), "Modeling the relative efficiency of national innovation systems." 
Research Policy, 41(1), 102-115.

Jaffe, A.B. (1989), "Real effects of academic research." The American Economic Review, 957-970.

Kalapouti, K., Petridis, K., Malesios, C. \& Dey, P.K. (2017), "Measuring efficiency of innovation using combined Data Envelopment Analysis and Structural Equation Modeling: empirical study in EU regions." Annals of Operations Research, 1-24. DOI: 10.1007/s10479-0172728-4

Khedhaouria, A. \& Thurik, R. (2017), "Configurational conditions of national innovation capability: A fuzzy set analysis approach." Technological Forecasting and Social Change, 120, 48-58. DOI: 10.1016/j.techfore.2017.04.005

Korber, M.,\& Paier, M. (2014), Simulating the effects of public funding on research in life sciences: direct research funds versus tax incentives. In Simulating knowledge dynamics in innovation networks. Springer: Berlin, Heidelberg. 99-130.

Korber, M. \& Paier, M. (2013), Effects of competence centres on regional knowledge production: An agent-based simulation of the Vienna life sciences innovation system. In The Geography of Networks and $R \& D$ Collaborations. Springer, Cham. 353-371.

Korber, M., Paier, M. \& Fischer, M. M. (2009), ”An agent-based view of the biotech innovation system." Reg Direct Int Sci J, 2(2), 33-55.

Kou, M., Chen, K., Wang, S. \& Shao, Y. (2016), "Measuring efficiencies of multi-period and multi-division systems associated with DEA: An application to OECD countries' national innovation systems." Expert Systems with Applications, 46, 494-510.

Kwon, S. \& Motohashi, K. (2017), "How institutional arrangements in the National Innovation System affect industrial competitiveness: A study of Japan and the US with multiagent simulation." Technological Forecasting and Social Change,n115, 221-235.

Lu, W.M., Kweh, Q.L. \& Huang, C.L. (2014), "Intellectual capital and national innovation systems performance." Knowledge-Based Systems, 71(1), 201-210. DOI: 10.1016/j.knosys.2014.08.001

Lundvall, B.Å. (Ed.) (1992), National systems of innovation: Toward a theory of innovation and interactive learning, Pinter: London

Malerba, F. (2002), "Sectoral systems of innovation and production." Research Policy, 31(2), 247264. DOI: $10.1016 / \mathrm{s} 0048-7333(01) 00139-1$

Matei, M. M. \& Aldea, A. (2012), "Ranking national innovation systems according to their technical efficiency." Procedia - Social and Behavioral Sciences, 62, 968-974. DOI: 10.1016/j.sbspro.2012.09.165

Meeusen, W. \& van Den Broeck, J. (1977), "Efficiency estimation from Cobb-Douglas production functions with composed error." International Economic Review, 18(2), 435-444. DOI: $10.2307 / 2525757$

Nasierowski, W. \& Arcelus, F.J. (2003), "On the efficiency of national innovation systems." Socio-Economic Planning Sciences, 37(3), 215234.

Nelson, R.R. (1993), National innovation systems: A comparative study. Oxford University Press: New York

Paier, M., Dünser, M., Scherngell, T. \& Martin, S. (2017), "Knowledge creation and research policy in science-based industries: an empirical agent-based model." In Innovation Networks for Regional Development. Springer, Cham. 153-183.

Ponsiglione, C., Quinto, I., \& Zollo, G. (2018), "Regional Innovation Systems as Complex Adaptive Systems: The Case of Lagging European Regions." Sustainability, 10(8), 2862. DOI: $10.3390 /$ su 10082862

Pyka, A., Gilbert, N., \& Ahrweiler, P. (2009), Agentbased modelling of innovation networks-the fairytale of spillover. In Innovation networks. Springer, Berlin, Heidelberg. 101-126.

Ragin, C. (1987), The comparative method: Moving beyond qualitative and quantitative methods. Berkeley: University of California.

Ragin, C.C. (2000), Fuzzy-set social science. University of Chicago Press.

Rihoux, B. (2006), "Qualitative comparative analysis (QCA) and related systematic comparative methods: Recent advances and remaining challenges for social science research." International Sociology, 21(5), 679-706. DOI: $10.1177 / 0268580906067836$

Rodríguez, J.C., \& Navarro-Chávez, C.L. (2015), "A system dynamics model of science, technology and innovation policy to sustain regional innovation systems in emerging economies." International Journal of Innovation and Regional Development, 6(1), 7-30. DOI: 10.1504/ijird.2015.067649

Samara, E., Georgiadis, P. \& Bakouros, I. (2012), "The impact of innovation policies on the performance of national innovation systems: A system dynamics analysis." Technovation, 32(11), 624-638. DOI: $10.1016 /$ j.technovation.2012.06.002 
Schrempf, B. \& Ahrweiler, P. (2014), Modelling the Emergence of a General Purpose Technology from a Knowledge Based Perspective: The Case of Nanotechnology. In Simulating Knowledge Dynamics in Innovation Networks. Springer, Berlin, Heidelberg. 201-216.

Sleuwaegen, L. \& Boiardi, P. (2014), "Creativity and regional innovation: Evidence from EU regions." Research Policy, 43(9), 1508-1522. DOI: 10.1016/j.respol.2014.03.014

Uriona, M. \& Grobbelaar S. S. (2019), "Innovation System Policy Analysis through System Dynamics Modelling: A Systematic Review." Science and Public Policy. DOI: 10.1093/ scipol/scy034

Varga, A. (1998), University research and regional innovation: a spatial econometric analysis of academic technology transfers (Vol. 13). Springer Science \& Business Media.

Varga, A. \& Horváth, M. (2014), Regional knowledge production function analysis. In Handbook of Research Methods and Applications in Economic Geography. Edward ElgarPublishing Ltd.. 511-543. DOI:10.4337/9780857932679.00033

Walrave, B., \& Raven, R. (2016), "Modelling the dynamics of technological innovation systems." Research Policy, 45(9), 1833-1844. DOI: 10.1016/j.respol.2016.05.011
Zabala-Iturriagagoitia, J. M., Voigt, P., Gutiérrez-Gracia, A., \& Jiménez-Sáez, F. (2007), "Regional innovation systems: how to assess performance." Regional Studies, 41(5), 661672. DOI: $10.1080 / 00343400601120270$ 
Varga-Csajkás Anna, tudományos segédmunkatárs csajkas.anna@ktk.pte.hu

MTA-PTE Innováció és Gazdasági Növekedés Kutatócsoport Pécsi Tudományegyetem Közgazdaságtudományi Kar Regionális Innováció- és Vállalkozáskutató Központ (RIERC)

\section{A mapping and summary of measurement methods for innovation systems}

\section{THE AIMS OF THE PAPER}

This study aims to summarize, what kind of methods can be used for measuring and modeling the performance of innovation systems. The presented methods can be classified into three groups according to their functions. The first group consists of methods that can measure and compare the performance of innovation systems of different nations or regions. The second group involves statistical models that explain the effect of different factors on innovative performance. The third group includes simulation methods, which can be used to model complex and dynamic relationships.

\section{METHODOLOGY}

This is a descriptive study, which presents and groups the methods for modeling and measuring innovation systems. After introducing the different tools, illustrative examples are given to show what kind of analyses can be conducted with each methodology.

\section{MOST IMPORTANT RESULTS}

The examined methods are different according to their functions, complexity and the quality and quantity of required data. Therefore, one can choose the appropriate method according to the aim of the analysis and available data. Composite indicators are good starting points since they are able to capture a wide range of indicators with one value. However, the measurement of innovation systems' efficiency can be an important complement to them. The different statistical and econometrical methods are able to analyze the correlation between the inputs and outputs of innovation. The complexity of innovation systems can be best tackled by the simulation methods.

\section{RECOMMENDATIONS}

Each of the examined methods can be used for supporting policy-making. With the help of composite indicators, one can analyze its different dimensions and define the strengths and weaknesses of the system, where policy intervention is needed. Simulation models are suitable for ex-ante analysis of policy interventions by comparing different scenarios.

Keywords: innovation systems, methodology, composite indicators, knowledge production function, simulation models

Acknowledgements: This publication/research has been supported by the European Union and Hungary and co-financed by the European Social Fund through the project EFOP-3.6.2-16-2017-00017, titled ,Sustainable, intelligent and inclusive regional and city models”. 